\title{
The Rebirth of Cultural Colonialism as Religionswissenschaft: Rudolf Otto's Import House
}

\author{
GREGORY D. ALLES \\ McDaniel College
}

\begin{abstract}
During his 'world journey' of 1911-1912, Rudolf Otto came to embrace a form of German cultural colonialism which assigned the study of religions a key role. Concern for this colonial program guided his activities until the outbreak of World War I, when German colonial ambitions became unrealistic. Although it is difficult to argue that this colonial project had a major impact on Otto's conception of religion, it did alter his scholarly practice with regard to it, transforming him from a liberal systematic theologian into something more akin to what we know today as a scholar of religions. For 25 years, fom 1912 until his death in 1937, much of Otto's professional activity was taken up with importing religious materials from elsewhere, especially from south Asia-mostly texts but also material artefacts. This article reads Otto's colonialism and its rebirth as Religionswissenschaft against the grain of Otto's self-conception and the conception of others at the time. While cultural colonialism insisted upon its distance from the activities of the business classes, this article reads those activities in mercantile terms. In doing so, it suggests that such a re-reading might be profitably applied not just to conceptions of scholarly activity but also to other areas where it has been customary to insist on distance from economic activity, specifically, the way in which scholars of religions have conceived what we usually call religion.
\end{abstract}

Keywords: Rudolf Otto, colonialism, study of religion

In 1911-1912 Rudolf Otto made a 'journey around the world'. According to later legend, he made a major discovery during this trip: in a North African synagogue he discovered the experience of the Holy (Frick 1937, 5-6; Benz 1971, 36). To judge from the report that Otto filed with the German government on his return (Otto 1912b), however, as well as from his activities in the years that immediately followed, the discovery is more myth than history. What Otto actually discovered abroad he seems to have found in China, 
and that was German colonialism, largely of the 'moral' variety advocated by the German publicist Paul Rohrbach and reminiscent of the policies of the German East Asia Mission (Allgemeiner Evangelisch- Protestantischer Missionsverein, hereafter A.E.P.M.V.) (cf. Mogk 1972).

In what follows, I re-read the practice of Otto's Religionswissenschaft (science of religion) through the lens of his colonial project, or - more accurately - through the lens of that project's failure. In doing so, I deliberately cut against the grain of what I take to be one common way of representing academic pursuits, namely as of a different order from the world of business. (For Otto himself on interest-free science, see Otto 1927.) Specifically, I view Otto's Religionswissenschaft as a kind of cultural import business, and one that was a relic, in some sense a post-colonial one, of a more ambitious importexport endeavor that could not survive the force of political circumstances. My ultimate aim is neither to use Otto's motives to impugn his scholarship nor to call into question the pretensions with which academics sometimes see their work. That is rather common fare these days (in the case of the study of religion, see, paradigmatically, Strenski 1987; McCutcheon 1997). It is rather to point eventually to some ways in which scholars of religion in the tradition of Otto - and I count myself, however remotely, as one of them - might wish to broaden their work.

\section{Otto's Cultural Colonialism}

Before his trip to North Africa in 1911 and Asia in 1911-1912, Otto could hardly have been unaware of colonialism, whether German or European. He was relatively well traveled, having visited Greece with Heinrich Hackmann as early as 1891 (Otto 1941; cf. 1897a). He also had relatives living overseas - in Tenerife and South America. As a theology student he had worked in Cannes under the supervision of the socially active Protestant minister, Hermann Schmidt (Otto 1911a). As the Prussian church authorities disapproved of his liberal theological inclinations, he initially planned to serve a church in Paris (Otto 1897b), just as his friend, Heinrich Hackmann, the future sinologist who served as pastor of the German community in Shanghai from 1894, would later serve a church in London (Strachotta 1997). As a student and young instructor Otto joined Friedrich Naumann's Nationalsozialer Verein, which advocated a strong German foreign policy (cf. Düding 1972; on Naumann, see Otto 1904b). When the Verein collapsed in 1903, if not before, Otto became actively involved in a group known as 'The Friends of Die Christliche Welt'. (Die Christliche Welt was a quasi-popular magazine for liberal Protestants.) As one sees from their newsletters (Schwöbel 1993), 
the Friends received regular reports as well as requests for funds from the German East Asia Mission, or as it was known then, the A.E.P.M.V.

Despite these reports and requests, the Friends seem to have had little real interest in overseas missions, and Otto seems to have had just as little. His concerns were with domestic issues, both ecclesiastical and social. He established a fund to support liberal candidates for the Protestant ministry; at the time these candidates were extremely unpopular with the Prussian authorities (Otto 1910a; 1911a; 1911b; 1913a). He tried to provide a musical alternative to the Apostles' Creed that all Protestant Christians could use without mental reservation (Otto 1911c; 1911d; 1911e; 1913b). In addition, as a leading member of the Göttingen chapter of the Akademischer Freibund, he championed the view that the most pressing need of the day was not an economic but a weltanschaulich one: specifically, the cultivation of a Weltanschauung or worldview that was open to religious and moral dimensions in the face of materialism and biological evolutionism. Movements characterized by such views included both 'Manchester liberalism' and German socialism (cf. Bousset 1909; for Otto on evolution, Otto 1904a; for the Akademischer Freibund, Rade 1912).

During his 'world tour' of 1911-1912, however, Otto's program changed. He did not abandon his commitment to an idealistic worldview, but he now inserted it into a cultural colonialist agenda that had very different horizons. The result was that he went from being a philosophical theologian interested in advancing the cause of liberal theology at home into one who spent much of the rest of his life writing about and in that sense importing Asian religions into Europe, at times quite concretely, as in the collection of artefacts that he brought from India for his Religionskundliche Sammlung in 1927-1928.

It is not possible - and I do not mean merely here - to trace the evolution of Otto's cultural colonialism in detail, but we can identify a few high points. While visiting North Africa in 1911, Otto was struck by contrasts between tradition and modernity. For example, he criticized the madrasas for promoting learning through memorization, while he found a quasireligious sublimity in the British military installations on Gibraltar: they demonstrated what a people could accomplish if only it had the will (Otto 1911f). Yet as a German traveler, Otto was neither colonizer nor colonized. An Anglophile from childhood, who had served for a year as vicar in Cannes and had planned to take a church in Paris, he could nevertheless not identify with the British or the French. After all, he visited Morocco in the year of the Agadir crisis (e.g., Barlow 1940; Barraclough 1982). He envied the British 
and French, but at the same time he found their outlook superficial. And as a liberal theologian attuned to nationalistic ambitions rooted in religion - even as a student he had written on the conjunction of liberal theology and the Greek struggle for independence (Otto 1894) - he could not blithely ignore the aspirations of young, modernizing Arabs, fighting for freedom, however much this was at odds with European colonial ambitions.

On his way to East Asia Otto encountered at first hand Indian aspirations for independence. He also preached in India the glories of Friesian Kantianism and the German language, perhaps acquiring at the same time a desire to learn Sanskrit (e.g., Otto 1911g). By the time he left China, he was no longer a stranger traveling through a strange land. He had discovered a proper place for both his nation and himself in a dominate-or-be-dominated world. In a talk before the German consul in China, he confidently outlined a cultural colonial program (Otto 1912a).

Otto's program was probably not a unique creation ex nihilo. He was presumably influenced by the missionaries of the A.E.P.M.V. Their activities were far from the usual stereotype of the Christian missionary:

Under the leadership of Richard Wilhelm, the [A.E.P.M.V.] [...] refrained from baptizing Chinese converts and founding native congregations. Neither did it hold any religious instruction sessions nor celebrate Christian holidays in the boys' school. Instead, it actively supported a thorough Confucian training in the mission schools and promoted Confucianism in China and Germany. (Gerber 2004, 22; cf. Shimazono 1980.)

The Richard Wilhelm who led the China missions was the same Richard Wilhelm whose translations of The Secret of the Golden Flower and the Yi Jing so interested C. G. Jung (Jung \& Wilhelm 1929; Wilhelm 1950; cf. Hsia 2003). Although Wilhelm may have been on health leave during Otto's visit, Otto seems to have been particularly taken by him. In 1912 and 1913 Otto maintained an especially vigorous correspondence with Wilhelm, which, to judge from the preserved letters (at least forty in the Otto Archiv and Nachlaß in Marburg), resumed in 1920 and continued with less intensity until Wilhelm's death in 1930.

The possible influence of other Germans whom Otto met in China and Japan, whether missionaries or not, is more difficult to determine. But another recent visitor to A.E.P.M.V. missions in China, the publicist Paul Rohrbach, may have exerted even more influence on Otto than Wilhelm. At the beginning of the twentieth century Rohrbach tried to become a theologian but 
failed; his views on the kingdom of God on earth alienated his teacher, Adolf von Harnack in Berlin. After this misadventure he turned to colonial administration in German Southwest Africa, where he worked from 1903 to 1906. His program for German colonization began with the assumption that the era of old-style administrative colonialism was over (cf. Rohrbach 1908; 1910; 1912a; 1912b). The world was already 'saturated' in terms of colonies, just as Bismarck had earlier described Europe as saturated in terms of land - or lack thereof - for excess population. As a result, Rohrbach turned to what he called ethical imperialism, that is, to a contest for cultural dominance and the benefits that accrued from it. There is no evidence that Otto knew Rohrbach in the early 1900s, although the two did move in some of the same circles. By the mid-1910s, however, Otto certainly knew, or knew of, Rohrbach. In 1915, when it looked as if he would have to surrender his seat in the Prussian state legislature to assume a professoriate at Breslau, Otto recommended Rohrbach as a possible replacement (Otto n.d.; 1915). In 1917 he published three lengthy opinion pieces in Rohrbach's political journal, Deutsche Politik (Otto 1917a; 1917b; 1917c). Later, in the 1920s, Otto became a senator of the Academy for Furthering Germanness, an organization that Rohrbach headed from 1927 to 1929 . Nevertheless, Otto's colonialism did not simply replicate Rohrbach's. What distinguished it was its emphasis on what we might call the holy, a term that Otto was not yet using. (Söderblom's influential account of 'Holiness' in Hastings' encyclopedia only appeared in 1912.)

In fundamentals, Otto's program went something like this (I am summarizing Otto 1912a and the last pages of Otto 1912b.): In the 1910s the colonial struggle was no longer for overseas territory and government; it was for the hearts and minds of people overseas. Victory in that struggle ensured many benefits, among them trading partners for German goods and allies in times of international tension and war. It was possible for Germany to engage in this struggle by establishing educational institutions and cultural programs, but these had to be the right kind of institutions and programs. A technical education, such as the British and French were giving, alienated students from their own cultures. The German ideal of Bildung allowed Germany to do better. It would not only educate pupils technically but also provide a more general cultural education to shape or nurture their personalities. The ideal foundation for this more general education was moral and religious, and the best way to incorporate that foundation into an educational program was through the comparative study of religions. Such an education included the best that the locals had to offer, but at its core stood the essence of religion, and that was nothing less than the central concern and substance of modern 
[German Protestant] theology. One should not overlook that Otto had set out on his world journey to prepare an introduction to the world's religions that he was supposed to write for Paul Siebeck (Otto 1909b; 1910b; Siebeck 1909). Among other things, his program of cultural colonialism would have created an international market for his text. By the time Otto returned home, he had expanded his program even further. It was to include a systematic, collaborative effort to import Asian religions into Europe, especially in German translation, to counter the cultural capital that Britain had accumulated from Orientalist scholarship, notably the Sacred Books of the East - founded, Otto pointed out, by a German (Otto 1912b).

Of Otto's many colonialist dreams, only one really came true: the series of translations intended as the German counterpart to the Sacred Books of the East, Quellen der Religionsgeschichte. Otto helped found the series, published by the Göttingen Academy of Sciences (Otto 1913c; 1913d; 1913e; 1913f), and as a Prussian legislator he procured government funds for it (Otto 1914). The project seems to fit into a well-known frame in which, on the analogy of the Bible in Christianity but also of the Torah in Judaism and the Qur'an in Islam, Europeans assigned privilege to textuality, especially ancient texts, in discussing Asian religions. It seemed to matter little how important the texts translated in the series-prior to World War I, the Dighanikāya, the Rgveda, the Aștasāhasrikā-prajñāpāramitā-sūtra, or the Vajracchedikā-prajñāpāramitāsūtra (Franke 1913; Hillebrandt 1913; Walleser 1914) - were to ordinary Hindus and Buddhists. A culture's religious-moral core lay in its texts. But these observations need two important qualifications. First, although most of the subsequent volumes in the series were also devoted to translations of classic texts, three volumes co-opted into Quellen from an earlier series, Religionsurkunden der Völker, were different. Only one of them, on Pure Land Buddhism, was a collection of texts (Haas 1910). The other two were ethnographic accounts of the Batak in Indonesia (Warneck 1909) and the Ewe in Togo (Spieth 1911). Second, and of greater consequence, Otto did not overlook the materiality of religion. Already in the period immediately after his world tour he seems to have conceived of the idea of a museum of the history of religions as the common person's complement to Quellen, even if the Religionskundliche Sammlung in Marburg would not become a reality until the late 1920s (Otto et al. 1926, 1; cf. Kraatz 1977). Later, writing about his encounter with the famous head of Siva on Elephanta island, he would note that this image, at least, had a greater power to evoke the experience of the holy than did descriptions in books (Otto 1938). If the majority of the religious objects that Otto imported into Germany consisted of texts rather 
than physical artefacts, this was probably due as much to practical limitations - lower procurement and transportation costs, greater demand among potential customers - as to any conviction that textuality was somehow the primary conveyor of religiosity.

We might say, then, that in the years immediately following his world tour Otto went into the import-export business. In addition to his work on the Quellen der Religionsgeschichte, he lobbied German publishers at the request of the German government, sought to help Wilhelm found a German cultural journal in China, and had a Chinese gentleman live in his house, whom he and his sister, Johanne Ottmer (with whom he lived), called Ben. His concern also found political expression: in 1913 Otto was elected to a seat in the Prussian legislature from the National Liberal party. More reflectively, we might say that Otto's colonialism combined three elements: (a) Schleiermacher's view that religion belonged to its own special domain, divorced from both pure and practical reason - framed, of course, in terms of the Ahndung identified by Jakob Friedrich Fries; (b) Schleiermacher's presumption that the supreme expression of this domain was the Christian intuition of the Infinite; and (c) a late rather than early nineteenth century colonial mentality that saw the main division of the world as one between East and West, one in which Germany, as an aspiring Western power in competition with France and above all Britain, confronted the East. Those who know Otto's work will recognize that this combination characterizes much of his mature activity.

\section{The Rebirth of Cultural Colonialism as Religionswissenschaft}

In another essay (Alles 2007), I have argued that it would be wrong to see the outlines of Otto's views on the Holy as an outgrowth of his colonial program. On the one hand, those views existed before Otto turned to cultural colonialism, and they responded to personal concerns, issues within Germany, and at most concerns among Western Europeans. Among these issues and concerns were the challenges that evolutionary theory and historical study, especially historical study of the Bible, posed to the traditional faith in which Otto was raised; the tension between the rising Besitzbürgertum, the business classes, into which Otto was born, and the Bildungsbürgertum, the educated elite, which as a university professor he joined; the furthering of the stature of the German nation-state in the eyes of a man born in the state of Hannover and an Anglophile from youth but nevertheless politically loyal to the German empire; and perhaps (this is controversial) even his self-identity as a gay man in a world dominated by heterosexual, patriarchal orthodoxy. 
(As a young instructor, Otto was active in promoting theological education for women and had the distinction of supervising the first doctoral thesis in theology written by a German woman; cf. Otto 1903.)

When it came to political purposes, Otto's notions about the experiential core of religion proved remarkably flexible. Otto adapted them to the variety of political positions to which he successively adhered. Throughout the first decade of the twentieth century he was active in pursuing moderately liberal (but anti-socialist) domestic policies, showing little interest in politics outside Germany. From 1912 up to the outbreak of World War I he turned to foreign policy with his cultural colonialism. During World War I, as a member of the Prussian legislature, he avidly supported the German nation but nevertheless sought political reform for the Prussian state (Otto 1917a; 1917b; 1917c). After the War, he adopted a rather radical, socialistleaning form of politics, especially as applied to the church (Otto 1919), only to turn to a policy of fostering international cooperation and seeking justice for oppressed nations, including a defeated Germany, in the 1920s and early 1930s (Alles 1991; Obergethmann 1998). In the early Nazi years - Otto died in 1937 - although he distanced himself from the excesses of the German Christians and the German Faith Movement, he also returned with enthusiasm to the classroom and opportunistically exploited possibilities of support from the Nazi regime (Alles 2002). Indeed, through the medium of archival footage, he even put in a posthumous, cameo appearance in a 1985 made-for-television film about the Nazi period, lecturing to Nazi students in a university classroom ('Die Mitläufer' [The Collaborators] 1985). What all of these positions have in common is not so much a colonial attitude toward the rest of the world, with which in any case Germany had a short and checkered history, but rather a devotion to the advancement of the German state, in whatever circumstances that state happened to be. One must, however, be cautious even in arguing that there was a necessary connection between Otto's views on religion and German nationalism. The philosopher from whom Otto learned the Friesianism that served as the framework for many of his views, Leonard Nelson, was a left liberal, then a socialist and a pacifist. As head of the Göttingen chapter of the Akademischer Freibund, an organization in which Otto was also active, Nelson was routinely harassed by nationalist students. His employer, the University of Göttingen, was not entirely happy with Nelson's politics either (Fischer 1999).

Nevertheless, as a matter of biographical fact, Otto's colonial adventure had a major impact on his work. This was not primarily an impact on the views for which Otto is known. By 1909 Otto had already come to call 
his work Religionswissenschaft, which he identified as the modern form of Protestant theology (Otto 1909a). He had developed in general outline the essential structures, although not the vocabulary, of the conceptualization of the numinous that would later appear in Das Heilige. He had come to see Religionsgeschichte, along with Religionsphilosophie and Religionspsychologie, as an integral component of the science of religion. He had even entered into an agreement to write an introduction to the world's religions. What the colonial adventure seems to have changed were not so much Otto's views and loyalties as his professional activities. It transformed him from a philosopher of religion into something more akin to what we today recognize as a scholar of religions, as distinct from a theologian. (By profession, Otto was always a systematic theologian.) Rather than simply reflecting on the world's religions in the context of broader philosophical and religious reflection on religion and society, Otto turned to the import-export business. Through translations, studies, and eventually material artefacts, but artefacts to be viewed and appreciated rather than bought and sold, he imported cultural and religious goods, especially but not exclusively from south Asia, into the world of the German academy, whence they then spread. His original plan was also to export cultural and religious goods from Germany, in order to advance Germany's standing in the world. Those export goods even included the German language, for Otto imagined that as a result of successful cultural colonial competition Germans would be able to insist upon using the German language abroad; a German pidgin would develop in those parts of the world where colonization proved successful, and German would even be able to compete successfully with English as the world's lingua franca (Otto 1912a). The years before World War I were indeed filled with heady dreams.

Circumstances quickly forced Otto to abandon his business's more properly colonial side, the export side. This is true despite the many translations of Das Heilige that appeared soon after the German original, and despite the Religiöser Menschheitsbund, in which oppressed peoples of the world, with the help of people of good will everywhere, were to rise up against the victorious powers of the League of Nations. (The 'uprising' was to be peaceful; the kind of resistance to colonial oppression that Otto favored in the 1920s was discussion between small groups of people from various religious backgrounds.) Once established in the import business, however, Otto never abandoned it. Somewhat like an import house that continues to purvey and sell products from a former colony, Otto continued to import religious goods from elsewhere, even though the political motivation for 
doing so had long since passed into the realm of impossibility. In these circumstances it is more accurate to characterize Otto's mature practice of Religionswissenschaft as post-colonial rather than colonial; it represents the rebirth or afterlife of a failed colonial project. (Colonialism remained a reality in other parts of Europe and in North America, and there the position of scholars was somewhat different.) What did this colonialism look like in its new incarnation?

Otto never did write the introductory overview of the world's religions (not 'world religions') that he had promised to Paul Siebeck. Once he started importing in full force, he still could have done so. The book could have become something like a catalogue of more specific products. But he did not. Nor did Otto ever publish translations in the Quellen der Religionsgeschichte. The outbreak of the war in 1914 temporarily halted the series, and Otto's move to Breslau in 1915 severed his ties with the series' sponsor, the Göttingen Academy of Sciences. But Otto did import, even in the midst of the war. We can identify three phases in which his import business expanded. The first phase began when Otto published translations from Indian texts in 1916. The second and third phases supplemented his translation activity. To the direct importation of cultural and religious goods, the second phase added explicit comparisons of the imported products with those produced at home. To translation and comparison, the third phase was to add the importation and display of physical artefacts. Planning for this phase began around 1926 with attempts to found the Religionskundliche Sammlung in Marburg (Otto et al. 1926), but the plans could not be fully implemented until after Otto's death. We should note that, as in any import business, these phases of expansion are schematic and do not exhaust the richness of the actual events themselves. They also do not provide a comprehensive account of all of Otto's mature activities; for example, they omit his mature attempts at liturgical reform. But they do encompass the structures of Otto's Religionswissenschaft in practice, as it continued beyond his failed colonial program. Let us examine each phase a little more closely.

As mentioned above, during phase one Otto began to import texts, which he made available in translation. This activity starts in 1916 (Otto 1916a; 1916b; 1916c; 1916d) and does not end until, somewhat paradoxically, well after Otto's death. The last volume of Otto's translations was published in 1943, although it reprinted translations published earlier (Otto 1943; cf. 1932, chaps. 5 \& 13). As one would expect, the production of translations takes place by fits and starts. It diminishes as other matters occupy Otto's attention, then resumes again. That is because Otto is operating as an independent 
importer, not running a firm. Furthermore, by the time Otto is working on the Bhagavadgita $\bar{a}$ toward the end of his life, he is doing considerably more than simply translating a Sanskrit text. He is also critically, if entirely speculatively, reconstructing the text and its history in the manner of some biblical scholars (Otto 1934; 1935a; 1935b).

It is relatively easy to criticize Otto's translations in terms of philological accuracy. What would one expect from someone who had somehow taught himself Sanskrit between the end of his journey in 1912 and the start of World War I, then published his first translations two years later? Furthermore, his attempt to reconstruct the phases through which the Git $\bar{a}$ developed seems bizarrely self-serving. It takes an important import item and tries to cut it up to conform to his theories. But there are perhaps other, more interesting observations that can be made. The texts Otto chose to import into Germany represented south Asian religions as a mixture of idealistic philosophy, mysticism, and Vaișnava religious devotionalism. None of them had much to say about actual religious practice or social organization, or for that matter the religious thought and behavior of most ordinary south Asians.

Those who have learned about Hinduism from European and North American textbooks will find in Otto's concentration on mystical elements in Vedānta philosophy, especially in its Advaita and Viśișțādvaita forms, and Vaișnava devotional traditions, a certain ring of familiarity. It comes as no surprise that Otto not only acted as translator for Rabindranath Tagore when Tagore visited Marburg but also tried to sell his own translations of Indian texts by cashing in on the Tagore name (Otto 1922a; 1931a; 1931b). Otto imports what amounts to an uncritically accepted neo-Hindu synthesis of what was allegedly best in the religions of south Asia. Perhaps that choice reflects the preferences of Otto's suppliers in India. Perhaps it reflects the preferences of his buyers in Germany. Or perhaps it reflects the preferences of both, as well as his own personal tastes. We know today that such a selection of import goods represents a very limited range of what we ordinarily call Hinduism (e.g., Sontheimer 2004; Michaels 2004, 12-30), and in Otto's case we can attribute those limitations to a very quick and superficial acquaintance with the Indian subcontinent on the part of an academic primarily encountering the educated elite. But we should not be too harsh on Otto for all that. On the one hand, as Axel Michaels concedes, even though we recognize that we are conceptualizing Hinduism from a limited, brahminic-Sanskritic perspective, most of us still persist in doing so at many levels. To take what I admit is a very minor example, 
how many of us tell our beginning students about radical departures from purānic traditions, for example, that Ganeśa is sometimes represented with a human head, riding a horse, and smoking a hookah? (This is how he is represented in the pithora paintings by Rathawas like Mansinghbhai, a gifted pithora painter in eastern Gujarat.) On the other hand, although Otto seems uncritically to swallow a certain neo-Hindu conception of south Asian religions, one must be careful not to impute to him views that he did not share. It is not at all clear that Otto was interested in giving a comprehensive account of south Asian religions. Rather, like some scholars today (Stietencron 1989), he generally refrained from speaking of Hinduism, seeing what is often called Hinduism as separate religious traditions and communities.

Phase two introduces the climax of Otto's import activity: his comparative studies, exemplified above all by Mysticism East and West (Otto 1926), which discussed the teachings of Śañkarācarya in comparison with Meister Eckhart, and India's Religion of Grace and Christianity (Otto 1930), which examined Śrī Vaiṣnava traditions stemming from Rāmānuja in comparison with Christian teachings of salvation by grace. As the titles of the books indicate, Otto sees two fundamental ways in which religious experience can manifest itself, corresponding roughly to the jũanna and bhakti traditions in India and an impersonal and personal conception of the numinous: mysticism and devotional piety, or in German, mystische und gläubige Frömmigkeit (e.g., Otto 1922b). But as the virtually identical subtitles of the two books indicate, Otto's comparative work fundamentally replicated the basic structures of his cultural colonialism. His projects are presented as Vergleich und Unterscheidung; they compare and at the same time differentiate. What needs to be compared and differentiated are the two halves into which the colonialist imagination divided the religious world, east and west, the one represented by Indian religions rather than China (I do not know what was responsible for that choice), the other primarily by German Christianity. It is obvious that this division leaves a great deal of the world unrepresented, but it is still replicated in North American textbooks as well as in courses with titles such as 'World Religions West' and 'World Religions East' (cf. the market forces that led Ludwig 2006a to be issued as Ludwig 2006b and 2006c). What Otto reveals through his comparative work is crucial: the same fundamental religious experience is present in both east and west. But what he reveals through differentiation is equally crucial: there is always some distinguishing feature that makes the German, Christian West superior. Somehow, the Christian West always manages more fully to actualize the potential 
contained in the core religious experience than does the non-Christian East. It did not, of course, need to be this way. The fit between Otto's analysis of the numinous and his comparative studies is not that tight. A gifted thinker could easily maintain the notion of the numinous as standing at religion's experiential core without assigning superiority to either east or west (cf., e.g., the attitudes implicit in Ludwig 2006b and 2006c). But in fact for Otto this was the way it was. This leads to a fundamental question about Otto's cultural colonialism, one at risk of being lost because Otto was writing his comparative studies at a time when he had to limit his activity to importing, because exporting was by and large no longer feasible. How can one expect to win over the hearts and minds, let alone the money, of people outside one's group by telling them that their own traditions are good, but one's own are better? One would think that people would find such an attitude rather annoying. But that is the perspective that Otto adopted, and one that he had to adopt, not simply because of the presumptuousness of a colonial mentality. His import business was always an odd one. As a professional theologian, Otto could not adopt the position that Indian traditions were just as valuable as Christianity. This put him in a somewhat self-contradictory position: he wanted to sell the products he was importing, but no matter what virtues he might claim for them, he was ultimately forced to proclaim that the home-grown products were better. People might acquire his imports, but they should not use them to replace Christianity. As one might expect, most of Otto's clientele, that is, most students of theology at the time, chose simply to reject his products. Most of Otto's successors in the import business - for example scholars of religions who teach in bachelor's programs in North America - no longer compare the cultural goods that they import with cultural goods produced domestically, at least not in an evaluative sense. One suspects that much of the contemporary market for such products finds them attractive because of a fascination with foreign goods.

Phase three was intended to broaden the import business beyond texts and books to physical artefacts and objects. Although Otto and his collaborators, especially Heinrich Frick, tried assiduously, they could not convince the authorities to fund a separate location for the Religionskundliche Sammlung during Otto's lifetime. But there was some movement toward implementing this phase of expansion. Otto made a major excursion to India in 1927-1928 to procure materials for the Religionskundliche Sammlung (Otto 1928). Upon his return, he and his collaborators managed to find a temporary home in which to display the materials, and they won promises for the granting of a permanent home. In the end, however, the 
Sammlung received a permanent place - and this phase of Otto's import business became fully implemented - only in 1947, ten years after Otto's death (Kraatz 1977, 385-387).

No one familiar with the story of the Elgin marbles (e.g., Hitchens 1997) or with the smuggling of antiquities from India today (e.g., Keefe 2007) can doubt that the venture of the Sammlung presents the potential for cultural theft. Indeed, I am personally disheartened by the evidence of destruction that one often encounters on Indian monuments, destruction carried out in order to transport cultural goods elsewhere, and when viewing collections of south Asian art in museums my general sense is that I would much rather have seen pieces of stone sculpture in situ instead of hopelessly divorced from their context. I must confess, however, that I have no evidence for Otto's collecting practices, whether for the sources of the art that he collected, the prices that he paid for it, or the manner in which he transported it. Given both the absence of evidence and the incompleteness of the venture by the time of Otto's death, it is perhaps best to leave discussion of this phase of his import business until such time as evidence becomes available.

\section{Broader Considerations}

The examination of colonialism in conjunction with academic practice in the study of religion is a tricky business. The same is equally true for any analysis that sees scholarly practice in terms of a reborn colonial endeavor. For one thing, it is extremely tempting to schematize someone else's scholarship in terms derived from our own deeply held commitments. For example: Edward Said's (1978) Orientalism was, and to my mind still is, a very important book, but it has had the effect of framing the history of scholarship in simple binary oppositions: east/west, colonizer/colonized, dominator/dominated, and so on. One problem with such an approach is that European countries did not have a single set of colonial ambitions, nor were they equally successful in achieving the ambitions that they had. That observation is, I think, particularly pertinent to the scholarship of Rudolf Otto.

There can be no doubt that in 1912 Otto advocated a policy of cultural colonialism, and that he actively pursued it from 1912 to 1914 . I also have little doubt that his cultural colonialism had an afterlife in his practice of the study of religions from the time that he returned from his journeys in 1912 until his death. But it is important not to ignore the complexities of Otto's situation. For one thing, although Otto's ideas could be used for colonial purposes, they arose to serve other ends, and once colonialism was no longer a viable option for Germans they continued to serve other ends. 
During Otto's travels, his peculiar position as a third party in the contact zone situated him between the colonizer and the colonized (each complex realities in their own right), so that at one and the same time he sympathized with the colonized and aspired to colonize. He attempted to resolve this tension with his program of cultural colonialism, what perhaps more pointedly Paul Rohrbach called an ethical imperialism. But that program failed: not because of its own contradictions, although those contradictions were certainly present, but from the force of external circumstances. Having lost the First World War, Germany was in no position to colonize anyone. As a result, Otto's turn from the philosophy of religion to the history of religions can be seen as a kind of post-colonial project, one that resulted not so much from a loss of past 'greatness' as from a frustrated ambition to achieve colonial greatness. It embodied, to be sure, a conviction of the superiority of Otto's own nation that is commensurate with a colonial attitude. But that conviction has other motivations aside from colonialism, and for its time it could be relatively charitable. Indeed, Otto's sense of Christian superiority was so charitable that at the time it received considerable theological criticism, although I have only hinted at this criticism above.

A second danger, even larger than excessive schematization, looms in characterizing Otto's Religionswissenschaft as cultural colonialism reborn. That is the tendency to reject specific claims because we reject the thinker's politics. As Robert Segal (2005) has noted recently, we cannot judge the results of scholarship, whether past or present, on the basis of the circumstances in which they were produced or the political ends which they served or serve. To do so carries no epistemological weight; it is merely to claim that our politics are better than someone else's. However vile we may consider our political opponents to be, it always remains possible that their analyses are more adequate than our own. Indeed, although I do not find it convincing, some might even argue that to conduct a successful import business, as Otto did, one must not only understand the market into which one is importing but the goods in which one is dealing. Be that as it may, we must judge scholarship above all on the basis of whether it is coherent and whether it corresponds to the data at hand. (This is true even if, unlike most philosophers of science, we adopt a coherence theory of truth; doing so merely alters the manner in which we conceptualize our data.) Although I am interested in Otto and his thought, I happen to reject much of his analysis. I do not do so because he was a colonialist. I do so because I believe his analysis is flawed.

But that is an argument for another day, so I end here with another ob- 
servation, one about contemporary practice in the study of religion. One point that emerges from an analysis of Otto and his context is the close connection between the structure of his thought and the aspirations of the German educated elite. These aspirations were pursued in competition with the aspirations of the business elite, and they inclined people like Otto to emphasize the importance of Bildung and religious experience over material and practical concerns. That emphasis lies at the heart of Otto's cultural colonialism. It was not German business and the German military that would make Germany great on the world stage; that was the path being pursued by Britain and France. Rather, it was German professors and German universities that would accomplish this. Unlike others, the educated elite were motivated by the interest of the nation, not by self-interest (cf. Rade 1912), and their activities did not impoverish people's souls (Otto 1912a). In such a context, to speak of scholarly activities as an import business would have been to destroy the very views upon which the activities depended.

We are today hardly beyond tensions between professors and business people. There may even be good reasons for those tensions. Think of the widespread academic criticism of global capitalism. But although we are not entitled to reject Otto's academic views - or anyone else's - because of their political location, recognizing a scholar's location may invite us to rethink her or his views. Here I want to suggest that we might profitably do just that. Although the study of religions has left much of Otto's legacy behind, at a deep-structural level Otto has bequeathed to us a view of religion that is analytically distinct from the rationality or irrationality that characterize the rest of human life. This is analytically limiting. For example, so far as I can see, for most people religion serves as a way to accumulate benefits, manage risks, and negotiate uncertainties. It might be good to recognize in these activities parallels to economic concerns. Indeed, it might be good to seek, as has Pierre Bourdieu, to efface the line which separates the economic from the religious and place the study of religions within 'a general science of the economy of practices [sic], capable of treating all practices [...] as economic practices directed towards the maximization of material or symbolic profit ${ }^{\prime}$ (Bourdieu 1977, 183).

Such a view is far removed from the vision of religion bequeathed to us by people like Rudolf Otto. But perhaps that is another benefit to studying the history of the discipline: in uncovering the circumstances in which ideas achieved their dominance, we free ourselves to question them and propose something new. 
Bibliography

\begin{abstract}
Alles, Gregory D.
1991 Rudolf Otto and the Politics of Utopia. - Religion 21, 235-256.

2002 The Science of Religions in a Fascist State: Rudolf Otto and Jakob Wilhelm Hauer during the Third Reich. - Religion 32(2), 177-204.

2007 Rudolf Otto, Cultural Colonialism and the 'Discovery' of the Holy. - Timothy Fitzgerald (ed.), The Sacred and the Secular: Historical and Colonial Contexts, 179-194. London: Equinox.
\end{abstract}

\title{
Barlow, Ima Christina
}

1940 The Agadir Crisis. Chapel Hill: University of North Carolina Press.

\section{Barraclough, Geoffrey}

1982 From Agadir to Armageddon: Anatomy of a Crisis. New York: Holmes and Meier.

\section{Benz, Ernst}

1971 Rudolf Otto als Theologe und Persönlichkeit. - Ernst Benz (ed.), Rudolf Otto's Bedeutung für die Religionswissenschaft und die Theologie Heute, 30-48. Leiden: E. J. Brill.

\section{Bourdieu, Pierre}

1977 Outline of a Theory of Practice. Trans. Richard Nice. Cambridge: Cambridge University Press.

\section{Bousset, Wilhelm}

1909 Letter to Paul Wernle. Göttingen, 6 June. Archiv RGS 798.

\section{Düding, Dieter}

1972 Der Nationalsoziale Verein. Die gescheiterte Versuch einer parteipolitischen Synthese von Nationalismus, Sozialismus und Liberalismus. Munich: R. Oldenbourg.

\section{Fischer, Ilse}

1999 Der Bestand Leonard Nelson im Archiv der sozialen Demokratie der Friedrich-Ebert-Stiftung. Bonn: Archiv der Sozialen Demokratie der Friedrich-Ebert-Stiftung.

\section{Franke, R. Otto (trans.)}

1913 Dïghanikāya. Das Buch der langen Texte des buddhistischen Kanons. (Quellen der Religionsgeschichte, 4.) Göttingen: Vandenhoeck \& Ruprecht.

\section{Frick, Heinrich}

1937 Rudolf Otto zum Gedächtnis: Trauerfeier für den am 6. März 1937 heimgegangenen Professor D. Rudolf Otto und Gedächtnisrede an seinem Sarg gehalten von Professor Heinrich Frick am 10. März 1937. Leipzig: Leopold Klotz. 


\section{Gerber, Lydia}

2004 The Role of German Missionaries in Post-Boxer North China. - Asia Pacific: Perspectives 5(1), 21-26.

Haas, Hans (trans.)

1910 Amida Buddha unsere Zuflucht: Urkunden zum Verständnis des japanischen Sukhāvatī-Buddhismus. Göttingen: Vandenhoeck \& Ruprecht.

Hillebrandt, Alfred (trans.)

1913 Lieder des Rgveda. (Quellen der Religionsgeschichte, 5.) Göttingen: Vandenhoeck \& Ruprecht.

Hitchens, Christopher

1997 The Elgin Marbles: Should They Be Returned to Greece? London: Verso.

Hsia, Adrian

2003 Richard Wilhelm's Reception of Confucianism in Comparison with James Legge's and Max Weber's. - Journal of Ecumenical Studies 40(1-2), 96-110.

Jung, Carl Gustav \& Richard Wilhelm

1929 Das Geheimnis der Goldenen Blüte. Ein chinesisches Lebensbuch. München: Dornverlag.

Keefe, Patrick Radden

2007 The Idol Thief. - The New Yorker (May 7).

\section{Kraatz, Martin}

1977 Die Religionskundliche Sammlung, eine Gründung Rudolf Ottos. - Ingeborg Schnack (ed.), Marburger Gelehrte in der ersten Hälfte des 20. Jahrhunderts, 382-389. Marburg: N. G. Elwert.

\section{Ludwig, Theodore M.}

2006a The Sacred Paths: Understanding the Religions of the World. 4th ed. Upper Saddle River NJ: Pearson Education.

2006b The Sacred Paths of the East. 3rd ed. Upper Saddle River NJ: Pearson Education.

2006c The Sacred Paths of the West. 3rd ed. Upper Saddle River NJ: Pearson Education.

\section{McCutcheon, Russell T.}

1997 Manufacturing Religion: The Discourse on Sui Generis Religion and the Politics of Nostalgia. New York: Oxford University Press.

\section{Michaels, Axel}

2004 Hinduism: Past and Present. Trans. Barbara Harshav. Princeton NJ: Princeton University Press. 


\section{'Mitläufer, Die'}

1985 Directed by Eberhard Itzenplitz and Erwin Leiser. EML Film.

\section{Mogk, Walter}

1972 Paul Rohrbach und das 'Größere Deutschland': Ethischer Imperialismus im Wilhelminischen Zeitalter: Ein Beitrag zur Geschichte des Kulturprotestantismus. Munich: Wilhelm Goldmann.

\section{Obergethmann, Frank}

1998 Rudolf Ottos 'Religiöser Menschheitsbund': Ein Kapitel interreligiöser Begegnung zwischen den Weltkriegen. - Zeitschrift für Religionswissenschaft 6, 79-106.

\section{Otto, Rudolf}

n.d. Undated letter to Hermann Mulert. UB Mbg Hs. 797:775.

1894 Einfluß der Aufklärung auf die griechische Kirche dargestellt an dem Lebensbilde des Eugenio Bulgaris. Erichsburg, summer semester.

1897a Briefe von einer Reise nach Ägypten, Jerusalem und dem Berge Athos um Ostern 1895. - Der Hannoversche Sonntagsbote. Evangelischlutherisches Volksblatt für Stadt und Land 1(5), 2-3; 6, 2-3; 8, 3-4; 9, 3-4; $10,2-4 ; 11,3-5 ; 14,3-4 ; 15,3-4 ; 16,2-4 ; 22,4-5 ; 23,4-5 ; 29,3-4 ; 31$, $4-6 ; 32,4-6 ; 35,3-6 ; 36,3-4$.

1897b Letter to Caroline Ruepke Otto (Otto's mother), Göttingen, April 17. UB Mbg 797:565.

1903 Kirchliche Aemter für Frauen. - Die christliche Welt 17 (39) (September 24), cols. 920-924.

1904a Naturalistische und religiöse Weltansicht. Tübingen: J. C. B. Mohr.

1904b Moderne Religionen. - Die christliche Welt 18(5), cols. 100-105 \& 13, cols. 297-299.

1909a Kantisch-Fries'sche Religionsphilosophie und ihre Anwendung auf die Theologie. Tübingen: J. C. B. Mohr.

1909b Proposal to Paul Siebeck for Einleitung in die Religionsgeschichte. Göttingen, 30 June. Archiv J. C. B. Mohr, Tübingen.

1910a Schleiermacherstiftung. Ein Vorschlag für die Nürnberger Tagung. - An die Freunde, 33 (September 20), cols. 369-370.

1910b Letter to Martin Rade. [Toward the end of the year.] UB Mbg, Hs. 839.

1911a Schmidt-Kandidaturen. - Kirchliche Gegenwart. Gemeindeblatt für Hannover 10, 7-9.

1911b Die Lehrkandidaturen. - An die Freunde, 37 (September 20), cols. 418-419.

1911c Ein erfreulicher Vorschlag. - Die christliche Welt 25(13) (March 30), cols. 304-306.

1911d Zu dem erfreulichen Vorschlage. - Die christliche Welt 25(14) (April 6), cols. 331-332.

1911e Das Bekenntnislied. - Die christliche Welt 25(39) (September 28), cols. 922-925.

1911f Vom Wege. - Die christliche Welt 25, cols. 705-710, 724-729, 759-761, 779-783. 
1911g Letter to Leonard Nelson. Benares, December 1. ASD, Nelson Nachlaß 31.

1912a Deutsche Kulturaufgaben im Ausland. - Der Ostasiatische Lloyd 26(23), 483-485 (with 484a \& b).

1912b Bericht über die Reise des Professors der Theologie D. Dr. Rudolf Otto als Stipendiaten der Kahnschen 'Stiftung für Auslandsreisen deutscher Gelehrten'. Göttingen, 29 December. GStA PK I. HA Rep. 76Vc, Sekt. 1, Tit. 8, Nr. 9, Beiheft 2.

1913a Die Lehrstiftung. - An die Freunde, 43 (January 14), col. 474.

1913b Das Glaubenslied. - An die Freunde, 43 (January 14), cols. 473-474.

1913c Quellen der Religionsgeschichte. Mitteilung 10. - Theologische Literaturzeitung 38(6) (March 15), col. 190.

1913d Quellen der Religionsgeschichte. Mitteilung 13. - Theologische Literaturzeitung 38 (9) (April 26), col. 285.

1913e Quellen der Religionsgeschichte. Mitteilung 17. - Theologische Literaturzeitung 38(12) (June 7), cols 381-382.

1913f Quellen der Religionsgeschichte. Mitteilung 23. - Theologische Literaturzeitung 38(15) (July 19), col. 476.

1914 Speech before the Prussian Legislature, 70th Meeting of the 22nd Legislative Period, Session 2 (May 2, 1914). - Wörtlicher Bericht über die Verhandlungen des Preußischen Abgeordnetenhauses (Berlin: Preußische Verlagsamt), cols. 5956-5960.

1915 Letter to Hermann Mulert. Göttingen, 22 March. UB Mbg Hs. 797:761.

1916a Dìpikā des Nivāsa; eine indische Heilslehre aus dem Sanskrit von Rudolf Otto. Tübingen, J. C. B. Mohr (P. Siebeck).

1916b Aller Meister Lehren. Zeitschrift für Missionskunde und Religionswissenschaft 31, 73-82, 97-116.

1916c Artha-pañcaka oder Die fünf Artikel. - Theologischen Studien und Kritiken 89, 253-282.

1916d Von indischer Frömmigkeit. - Die christliche Welt 30, 255-256, 348-350, 423-426, 528-530, 571-572, 727-729, 755.

1917a Reform des Wahlrechts jetzt!. - Deutsche Politik 2(21) (25 May), 669-672.

1917b Jedenfalls so frühzeitig. - Deutsche Politik 2(30) (27 July), 955-958.

1917c Warum hat England noch keine Brotkarte? - Deutsche Politik 2(40) (5 October), 1288-1290.

1919 Die Missionspflicht der Kirche gegenüber der religionslosen Gesellschaft. - Friedrich Thimme \& Ernst Rolffs (eds), Revolution und Kirche. Zur Neuordnung des Kirchenwesens im deutschen Volksstaat, 273-300. Berlin: Georg Reimer.

1922a Aus Rabindranath Thakkurs väterlicher Religion. - Die christliche Welt 36(1) (January 5), cols. 7-10, and 2 (January 12), cols. 22-23.

1922b Zum Verhältnisse von mystischer und gläubiger Frömmigkeit. - Zeitschrift für Theologie und Kirche 3, 255-265.

1926 West-östliche Mystik: Vergleich und Unterscheidung zur Wesensdeutung. Gotha: L. Klotz.

1927 Sinn und Aufgabe moderner Universität: Rede zur vierhundertjahrigen Jubelfeier der Philippina zu Marburg. Marburg: N. G. Elwert. 
1928 Bericht über eine Studienreise zu religionskundlichen Zwecken vom 18. Oktober bis 14. Mai 1927/28 nach Indian, Ägypten, Palästina, Kleinasien und Konstantinopel. An die Notgemeinschaft der deutschen Wissenschaft. Marburg, 6 November.

1930 Die Gnadenreligion Indiens und das Christentum: Vergleich und Unterscheidung. Gotha: L. Klotz.

1931a Rabindranath Tagore's Bekenntnis: Dem Dichter zum 70. Geburtstage gewidmet. Tübingen: Mohr.

$1931 b$ 'Meine Religion' von Rabindranath Tagore. - Westermanns Monatshefte 75, 345-350.

1932 Das Gefühl des Überweltlichen (Sensus Numinis). Munich: C. H. Beck.

1934 Die Urgestalt der Bhagavad-Gita. Tübingen: J. C. B. Mohr.

1935a Der Sang des Hehr-Erhabenen: Die Bhagavad-Gita. Stuttgart: W. Kohlhammer.

1935b Die Lehrtraktate der Bhagavad-Gita. Tübingen: J. C. B. Mohr.

1938 Briefe Rudolf Ottos von seiner Fahrt nach Indien und Ägypten. - Die christliche Welt 52 (24), cols. 985-990.

1941 Reisebriefe Rudolf Ottos aus Griechenland. - Die christliche Welt 55(9) (May 3), cols. 197-198. [Otto's letter to the Gehrichs, ca. Sept. 2, 1891, UBM 797:566.]

1943 Varuna-Hymnen des Rig-Veda. Religionsgeschichtliche Texte, ed. Gustav Mensching, vol. 1. Bonn: Ludwig Röhrscheid.

\section{Otto, Rudolf \& Heinrich Hermelink \& Jakob Wilhelm Hauer \& Friedrich Heiler}

1926 Lehrsammlung für die Religionsgeschichte und Konfessionskunde. To the Prussian Kulturministerium. Marburg, April 29. StAM, Best. 310, acc. 1983/15, Nr. 4224, Bd. 1, 1-3.

\section{Rade, Martin}

1912 Der Deutsche Akademische Freibund. Oeffentlicher Vortrag nach der Konstituierung einer Ortsgruppe des Akademischen Freibundes in Heidelberg gehalten am 15. November 1911. Munich: Buchhandlung Nationalverein.

\section{Rohrbach, Paul}

1908 Deutschland unter den Weltvölkern: Materiellen zur auswärtigen Politik. 2nd ed. Berlin-Schöneberg: Die Hilfe.

1910 Was steht für Deutschland in China auf dem Spiel. - Paul Rohrbach (ed.), Deutsche Kulturaufgaben in China: Beiträge zur Erkenntnis nationaler Verantwortlichkeit, 32-66. Berlin-Schöneberg: Die Hilfe.

1912a Der deutsche Gedanke in der Welt. Düsseldorf: Karl Robert Langewiesche.

1912b. Das 'Größere' Deutschland. - Arthur Schröter (ed.), Der Deutsche Staatsbürger, 2nd exp., 418-461. Leipzig: Carl Ernst Poeschel.

Said, Edward W.

1978 Orientalism. New York: Pantheon Books. 
Schwöbel, Christoph (ed.)

1993 An die Freunde: Vertrauliche d.i. nicht für die Öffentlichkeit bestimmte Mitteilungen (1903-1934). Intro. by Christoph Schwöbel. Berlin: Walter de Gruyter.

\section{Segal, Robert}

2005 Theories of Religion. - John R. Hinnells (ed.), The Routledge Companion to the Study of Religion, 49-60. London: Routledge.

\section{Shimazono Susumu}

1980 Review of Suzuki Norihisa. - Meiji shūkyō shichō no kenkyū: Shūkyōgaku kotohajime. Japanese Journal of Religious Studies 7(1) March.

Siebeck, Paul

1909 Letter to Rudolf Otto. Tübingen, 1 July. Archiv J. C. B. Mohr, Tübingen.

\section{Sontheimer, Günther-Dietz}

2004 Hinduism: The Five Components and their Interaction. - Heidrun Brückner \& Anne Feldhaus \& Aditya Malik (eds), Essays on Religion, Literature, and Law, 197-212. New Delhi: Indira Gandhi National Centre for the Arts.

Spieth, Jakob (trans.)

1911 Die Religion der Eweer in Süd-Togo. Göttingen: Vandenhoeck \& Ruprecht.

\section{Stietencron, $\mathrm{H}$. Von}

1989 Hinduism: On the Proper Use of a Deceptive Term. - Günther-Dietz Sontheimer \& Hermann Kulke (eds), Hinduism Reconsidered, 11-27. New Delhi: Manohar Publications.

\section{Strachotta, Fritz-Günter}

1997 Religiöses Ahnen, Sehnen und Suchen von der Theologie zur Religionsgeschichte: Heinrich Friedrich Hackmann, 1864-1935. Frankfurt am Main: P. Lang.

\section{Strenski, Ivan}

1987 Four Theories of Myth in Twentieth-Century History: Cassirer, Eliade, Lévi-Strauss, and Malinowski. Iowa City: University of Iowa Press.

Walleser, Max (trans.)

1914 Prajñāpāramitā: die Vollkommenheit der Erkenntnis nach indischen, tibetischen und chinesischen Quellen. (Quellen der Religionsgeschichte, 6.) Göttingen: Vandenhoeck \& Ruprecht.

Warneck, Johannes (trans.)

1909 Die Religion der Batak. Ein Paradigma für die animistischen Religionen des Indischen Archipels. Göttingen: Vandenhoeck \& Ruprecht. 


\section{Wilhelm, Richard}

1950 The I ching; or, Book of changes: The Richard Wilhelm translation rendered into English by Cary F. Baynes. Foreword by C. G. Jung. New York: Pantheon Books. 
